Jurnal Agro 7(2), 2020

\title{
ANALISIS DIVERSITAS MORFOLOGI DAN POTENSI PERSEBARAN MAJA (Aegle marmelos (L.) Corr. dan Crescentia cujete L.) DI MOJOKERTO
}

\section{MORPHOLOGICAL DIVERSITY ANALYSIS OF MAJA (Aegle marmelos (L.) Corr. and Crescentia cujete L.) AND THEIR POTENTIAL DISTRIBUTION IN MOJOKERTO}

\author{
Fakhri Hafidh, Budi Waluyo* \\ Jurusan Budidaya Pertanian, Fakultas Pertanian, Universitas Brawijaya \\ JI. Veteran, Malang 65145 Jawa Timur \\ *Korespondensi : budiwaluyo@ub.ac.id
}

Diterima : 17 Juni 2020 / Disetujui : 29 November 2020

\begin{abstract}
ABSTRAK
Tanaman maja memiliki sejarah vital bagi masyarakat Mojokerto. Selain simbol budaya, maja dimanfaatkan untuk peribadatan, keperluan medis, dan pertanian. Sekarang keanekaragaman hayati tanaman lokal ini terancam karena minimnya upaya pelestarian dan pendataan. Penelitian bertujuan untuk mengeksplorasi, memetakan sebaran dan potensi sebaran maja serta menganalisis keanekaragaman dan kekerabatannya berdasarkan morfologi. Metode eksplorasi didasari pada survey ekogeografi dan pemetaannya menggunakan model Maxent di aplikasi DivaGIS . Indeks Shannon digunakan untuk menganalisis keanekaragaman. Analisis kekerabatan menggunakan aplikasi DARwin dengan metode Neighbor-joining dan Hierarchical clustering. Hasil penelitian menunjukkan bahwa tingkat keanekaragaman hayati maja di Mojokerto tergolong sedang dengan nilai indeks 1,95. Kekerabatan maja terbagi atas 4 kelompok berdasarkan sifat kualitatif dan 3 kelompok berdasarkan kuantitatif. Maja menyebar di Mojokerto dan terkonsentrasi di 4 kecamatan yaitu Trowulan, Jetis, Kota Mojokerto, dan Ngoro. Berdasarkan perbandingan dengan prediksi Maxent, terjadi penurunan populasi maja secara masif di Mojokerto. Alih fungsi lahan dan substitusi tanaman adalah penyebab utama penurunan populasi tersebut.
\end{abstract}

Kata Kunci: Aegle marmelos, Crescentia cujete, keanekaragaman, kekerabatan, Mojokerto

\begin{abstract}
Maja has a vital role in Mojokerto civilization. Aside as a cultural symbol, maja also used as religious festivals, medical purpose, and agricultural practice. Today, the diversity of maja is endangered because of the minimum conservation. The research was conducted to map the actual and potential distribution of Maja. The research also analyzes the diversity and kinship of maja. The Maxent model in DivaGIS was used as the bases of the ecogeographical survey and mapping.. The morphological diversity of maja was assessed by Shannon index and the cluster analysis was carried out based on Neighbor-joining dan Hierarchical clustering method using DARwin software. The result shows that the diversity index of maja in Mojokerto is classified as medium with the value of 1.95. Maja's kinship is divided into 4 groups based on qualitative and 3 groups based on quantitative traits. Maja was spread in Mojokerto and concentrated in 4 subdistricts of Trowulan, Jetis, Mojokerto, and Ngoro. Based on the comparison with maxent
\end{abstract}


predictions, there is a massive maja population loss in Mojokerto. Land conversion and plant substitution is a major cause of decrease of maja population.

Key Words: Aegle marmelos, Crescentia cujete, diversity, kinship, Mojokerto

\section{PENDAHULUAN}

Indonesia merupakan negara dengan keanekaragaman hayati yang melimpah. Tidak jarang tiap daerah memiliki keanekaragaman yang berbeda. Di beberapa wilayah keunikan tersebut diadaptasi dan menjadi simbol budaya salah satunya adalah maja (Aegle marmelos).

Di Mojokerto, maja merupakan unsur budaya yang vital. Maja sering dimanfaatkan dalam ritual adat dan keagamaan (Lesly et al., 2017). Masyarakat juga menggunakan maja sebagai obat disentri (Lambole et al., 2010). Penelitian mutakhir menyebutkan maja berpotensi digunakan untuk terapi jantung dan diabetes (Atul et al., 2012; Khandre, 2016).

Saat ini maraknya industri di Mojokerto berdampak pada krisis identitas. Maja yang menjadi simbol identitas Mojokerto mengalami penurunan populasi. Ditambah minimnya pendataan dan pelestarian, keanekaragaman tanaman lokal ini terancam hilang. Salah satu upaya untuk mencegah penurunan populasi maja adalah dengan melakukan kegiatan konservasi maja di seluruh wilayah Mojokerto. Sehingga dilakukan kegiatan eksplorasi, pemetaan sebaran, dan karakterisasi morfologi sebagai tahap awal untuk pelestarian dan pendataan keanekaragaman hayati tersebut.

Kamau (1992) menyatakan eksplorasi secara umum dilakukan dengan memperkirakan keanekaragaman tanaman dalam satu kawasan dan tempo yang sama. Keanekaragaman dapat diketahui dengan mengolah data morfologi tanaman. Data morfologi didapatkan setelah melakukan karakterisasi terhadap tanaman yang dikoleksi. Selain data morfologi, data geografis dan ekologi juga diperlukan untuk membuat model sebarannya.

Model sebaran umumnya berupa peta. Zonneveld et al. (2011) menyatakan bahwa peta sebaran mengandung informasi penting tentang keanekaragaman yang ada di suatu area tertentu. Peta disusun dan diolah dengan berdasarkan pada koordinat aktual (Herbei et al., 2010). Software yang bisa digunakan untuk menyusun peta seperti DivaGIS, ArcGIS, QGIS, gVSIG, SAGA GIS, UDIG, dan lain lain

\section{BAHAN DAN METODE}

Eksplorasi dilakukan pada bulan Mei hingga September 2018. Area eksplorasi tidak spesifik namun menyeluruh di semua kecamatan di Mojokerto. Tidak adanya lokasi spesifik disebabkan informasi yang minim. Info lokasi maja didapatkan dari wawancara dengan warga lokal dan riset terdahulu.

Bahan yang diperlukan dalam penelitian adalah tanaman maja. Kamera, alat tulis, smartphone, thermohigrometer, dan deskriptor maja (PPV \& FRA, 2011) merupakan peralatan yang digunakan selama penelitian.

Penelitian menggunakan metode konfirmasi dan survey ekogeografi. Garis besar survei ekogeografi meliputi distribusi tanaman, keanekaragaman, dan hubungan antara lingkungan dengan tanaman (Álvarez et al., 2011). Berikut merupakan urutan kegiatan dalam pelaksanaan eksplorasi : 


\section{Pencarian Info Lokasi}

Info lokasi maja didapatkan dari wawancara dengan warga lokal dan riset terdahulu oleh Vinolia (2014). Berdasarkan wawancara, umumnya maja tumbuh atau ditanam di area mistis (makam, hutan, dan situs lokal), wisata (museum dan candi), dan peribadatan (wihara).

\section{Penentuan Rute Eksplorasi}

Rute lokasi eksplorasi ditentukan dengan mendahulukan area mistis, peribadatan, dan wisata. Random route dilakukan di kecamatan yang tidak terdapat ketiga situs tersebut.

\section{Survei dan Koleksi Data}

Survei dilakukan untuk mengetahui kondisi aktual dan sebaran maja. Pengambilan sampel menggunakan metode Marshall \& Brown (1975) yaitu mengoleksi tanaman secara acak dengan memperluas area pengambilan sampel. Setelah dikoleksi, sampel dikarakterisasi berdasarkan deskriptor PPV \& VR (2011).

\section{Analisis Data}

Diversitas Morfologi

Analisis diversitas morfologi dilakukan dengan 2 metode. Metode pertama berdasar pada analisis Shannon Index. Shannon Index memberikan informasi nilai keanekaragaman terbagi mulai dari rendah sedang, hingga tinggi (Indriyani et al., 2017) dengan rumus menurut Palaghianu (2014);

$$
H=-\sum_{i=1}^{s} p i \ln p i
$$

$\mathrm{Pi} \quad=$ Perbandingan $(\mathrm{n} / \mathrm{N})$ individu dari satu karakter tertentu yang ditemukan ( $\mathrm{n}$ ) dibagi dengan jumlah total individu yang ditemukan (N)

Ln = Logaritma natural

$\Sigma \quad=$ Jumlah kalkulasi

$\mathrm{s} \quad=$ Jumlah karakter
Metode kedua berdasar pada analisis kekerabatan yang diolah dengan software DARwin. DARwin secara umum fokus kepada pembentukan struktur keanekaragaman berdasarkan metode jarak. Analisis data dilakukan terpisah. Data kualitatif menggunakan metode NeighborJoining sedangkan data kuantitatif menggunakan metode Hierarchical Clustering.

\section{Pembuatan Peta Sebaran}

Peta sebaran diolah untuk mengetahui kondisi aktual (Miller, 2010) maja di Mojokerto. Data koordinat (Tabel 1) aktual diproyeksikan (Bartelme, 2012) dengan software DivaGIS. Selanjutnya proyeksi aktual dibandingkan dengan prediksi Maxent.

\section{HASIL DAN PEMBAHASAN}

Eksplorasi yang dilakukan di 19 kecamatan di Mojokerto berhasil mendapatkan 35 sampel. Sebagian besar sampel tanaman maja diambil dari situs candi dan makam.

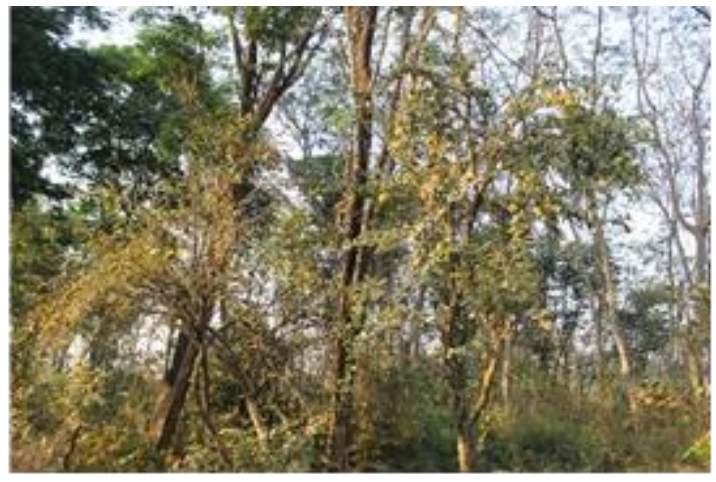

Gambar 1. Sampel pohon maja di daerah Jetis

Museum Majapahit di Kecamatan Trowulan memiliki jumlah populasi maja paling banyak. Populasi paling sedikit 
ditemukan di taman Surodinawan yang berada di kawasan Kota Mojokerto. Di daerah Jetis, eksplorasi dilakukan pada area kebun milik Perhutani. Pada area tersebut, terdapat populasi maja tumbuh liar dengan batang berdiameter besar dan pohonnya yang tinggi (Gambar 1). Diperkirakan bahwa populasi maja tersebut berumur tua dan tidak mengalami penebangan.

Tabel 1. Data lokasi ditemukannya maja

\begin{tabular}{|c|c|c|c|c|c|}
\hline Nama & Jenis & Latitude & Longitude & Elevasi & Kecamatan \\
\hline PTL 1 & C. cujete & -7.5153566 & 112.3962206 & 33 mdpl & Trowulan \\
\hline PTL 2 & C. cujete & -7.5153569 & 112.3962212 & 33 mdpl & Trowulan \\
\hline CG 1 & C. cujete & -7.5438811 & 112.3780416 & $42 \mathrm{mdpl}$ & Trowulan \\
\hline CG 2 & C. cujete & -7.5438807 & 112.3780426 & 42 mdpl & Trowulan \\
\hline CG 3 & C. cujete & -7.5438818 & 112.3780432 & 42 mdpl & Trowulan \\
\hline Brahu 3 & C. cujete & -7.5429944 & 112.3744052 & 38 mdpl & Trowulan \\
\hline S.Upas & C. cujete & -7.5702247 & 112.3799765 & $48 \mathrm{mdpl}$ & Trowulan \\
\hline TRL 1 & C. cujete & -7.5761465 & 112.3805311 & $48 \mathrm{mdpl}$ & Trowulan \\
\hline TRL 2 & C. cujete & -7.5761472 & 112.3805323 & $48 \mathrm{mdpl}$ & Trowulan \\
\hline TRL 3 & C. cujete & -7.5761469 & 112.3805317 & $48 \mathrm{mdpl}$ & Trowulan \\
\hline CT 1 & C. cujete & -7.5717670 & 112.4035294 & 59 mdpl & Trowulan \\
\hline CT 2 & C. cujete & -7.5717680 & 112.4035298 & 59 mdpl & Trowulan \\
\hline CT 3 & C. cujete & -7.5717676 & 112.4035299 & 59 mdpl & Trowulan \\
\hline PD & C. cujete & -7.572176 & 112.403271 & 59 mdpl & Trowulan \\
\hline CBJ 1 & C. cujete & -7.5677811 & 112.3987655 & 54 mdpl & Trowulan \\
\hline WLW & C. cujete & -7.5420053 & 112.3910929 & 44 mdpl & Trowulan \\
\hline WLW 2 & C. cujete & -7.542006 & 112.3910909 & 44 mdpl & Trowulan \\
\hline CBJ 2 & C. cujete & -7.5677809 & 112.3987651 & $54 \mathrm{mdpl}$ & Trowulan \\
\hline CBJ 3 & C. cujete & -7.5677800 & 112.3987647 & 54 mdpl & Trowulan \\
\hline PD SI & C. cujete & -7.546645 & 112.3725215 & 37 mdpl & Trowulan \\
\hline Museum & C. cujete & -7.560001 & 112.3806096 & 46 mdpl & Trowulan \\
\hline $\mathrm{CMJ}$ & C. cujete & -7.5581787 & 112.3863577 & 47 mdpl & Trowulan \\
\hline CMJ 2 & C. cujete & -7.5581780 & 112.3863582 & 47 mdpl & Trowulan \\
\hline CMJ 3 & C. cujete & -7.5581788 & 112.3863580 & 47 mdpl & Trowulan \\
\hline Sidorejo & C. cujete & -7.54973 & 112.634703 & $16 \mathrm{mdpl}$ & Ngoro \\
\hline CJ & C. cujete & -7.5801544 & 112.6130569 & $225 \mathrm{mdpl}$ & Ngoro \\
\hline CJ 2 & C. cujete & -7.5801533 & 112.613057 & 225 mdpl & Ngoro \\
\hline CJ 3 & C. cujete & -7.5801526 & 112.613057 & $225 \mathrm{mdpl}$ & Ngoro \\
\hline Jetis 1 & C. cujete & -7.38390109 & 112.467479 & 56 mdpl & Jetis \\
\hline Jetis 2 & C. cujete & -7.38390111 & 112.467485 & 56 mdpl & Jetis \\
\hline jetis 3 & C. cujete & -7.38390099 & 112.4674846 & $56 \mathrm{mdpl}$ & Jetis \\
\hline Surodinawan & C. cujete & -7.4820931 & 112.4235637 & $25 \mathrm{mdpl}$ & Kota \\
\hline Brahu 1 & A. marmelos & -7.5429944 & 112.3744052 & $38 \mathrm{mdpl}$ & Trowulan \\
\hline Brahu 2 & A. marmelos & -7.5429954 & 112.3744061 & $38 \mathrm{mdpl}$ & Trowulan \\
\hline HYW & A. marmelos & -7.5125036 & 112.3883886 & 31 mdpl & Trowulan \\
\hline
\end{tabular}




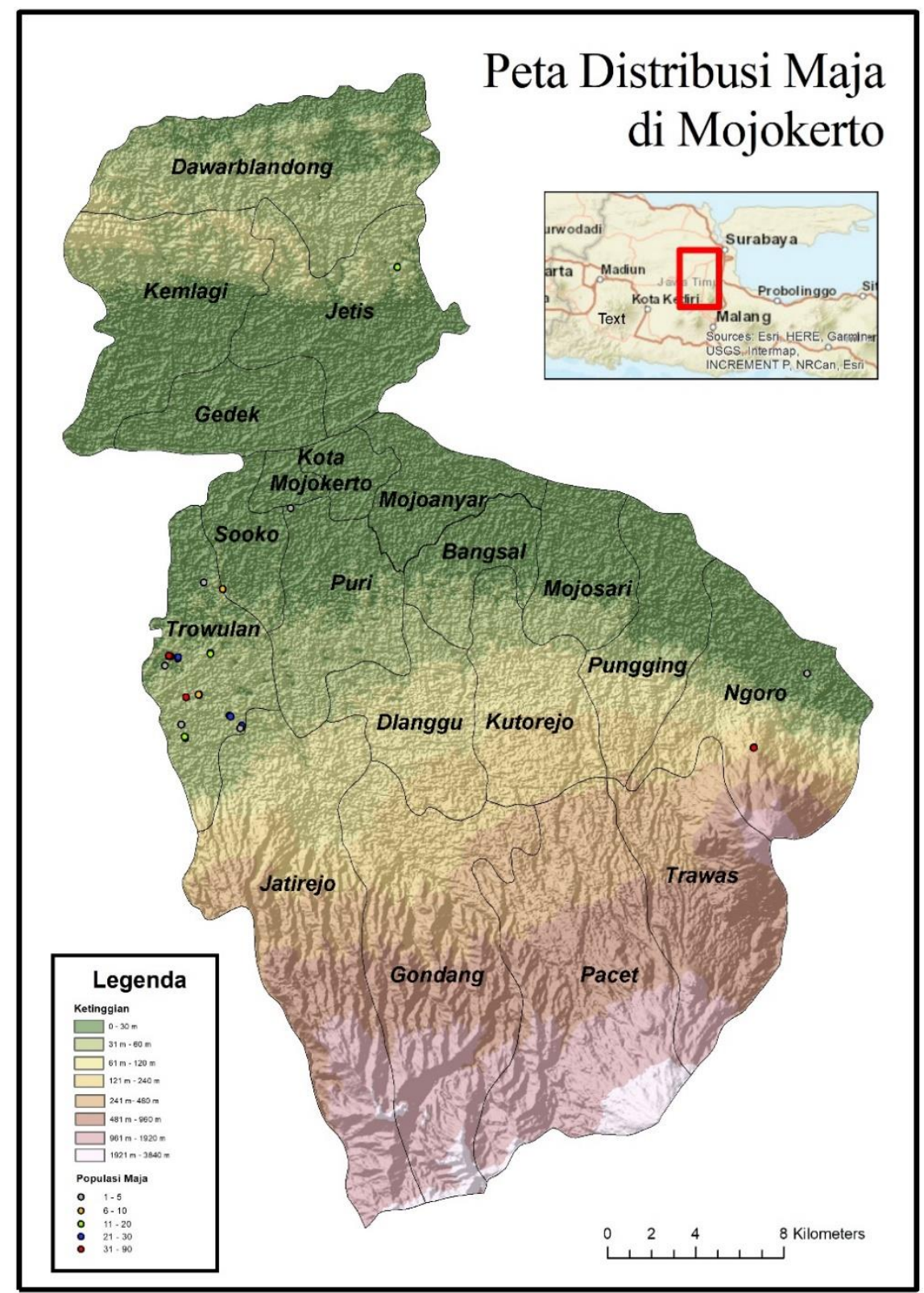

Gambar 2. Peta distribusi maja di Mojokerto

Trowulan, Sooko, Puri, Mojoanyar, Bangsal, Mojosari, dan Ngoro termasuk daerah yang level penurunan populasi maja rendah (Gambar 2). Rendahnya penurunan populasi maja di daerah tersebut dikarenakan banyaknya situs sejarah. Pihak pengelola menuturkan adanya arahan penanaman maja di situs bersejarah oleh pemerintah. Crescentia cujete adalah maja yang umum ditanam di situs. Hanya ada 2 situs yang menanam $A$. marmelos yaitu candi Brahu dan Petilasan Hayam Wuruk.

Model distribusi dapat digambarkan melalui dua metode, Model distribusi aktual (MDA) dan prediksi distribusi Maxent (PDM). MDA menggambarkan daerah distribusi maja hasil eksplorasi sedangkan PDM menjelaskan daerah potensial ditemukannya maja berdasarkan iklim dan daya tumbuhnya. Berdasarkan prediksi distribusi Maxent, ketinggian 0-400 m dpl 

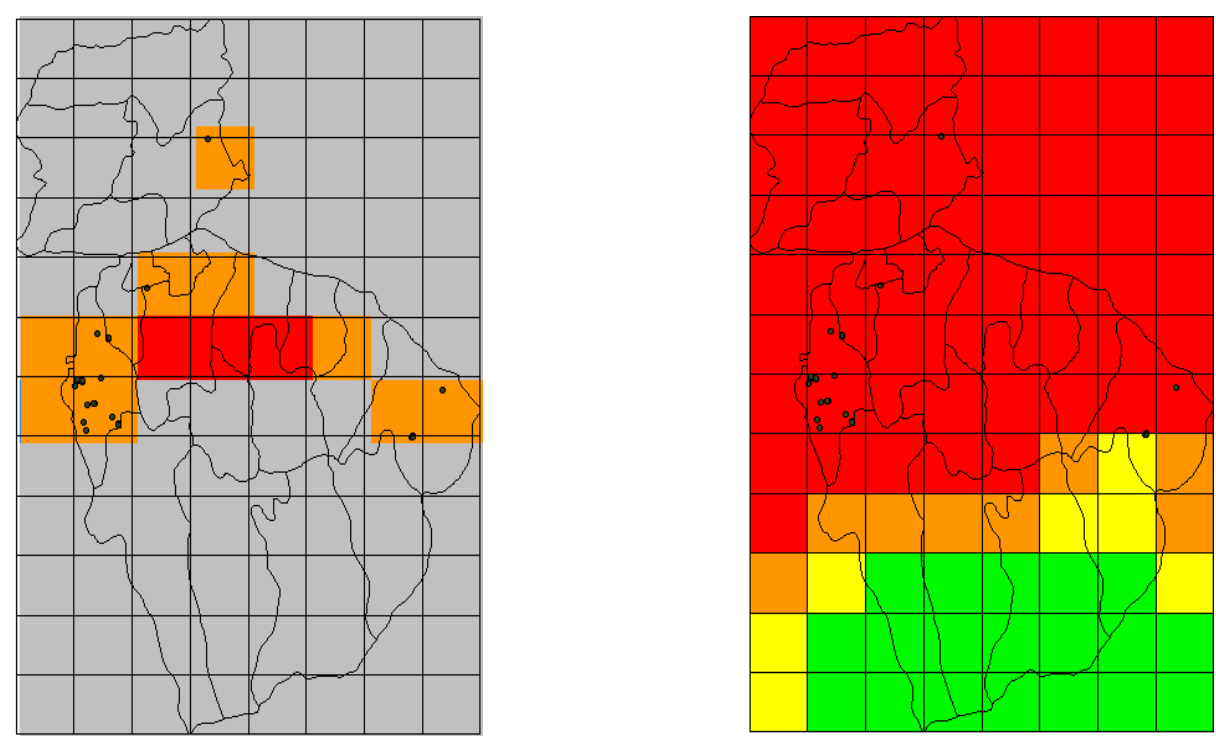

Gambar 3. Model distribusi aktual (kiri), peta kecamatan di Mojokerto, dan prediksi distribusi maxent (kanan). Jumlah populasi dilambangkan dengan; $\square$ tidak ada, sedang, tinggi, sangat tinggi, paling tinggi

merupakan ketinggian optimal maja. Namun demikian Orwa et al. (2009) menyatakan bahwa maja masih mampu beradaptasi hingga ketinggian $1200 \mathrm{~m}$ dpl.

Ada perbedaan signifikan antara PDM dengan MDA. Pada PDM (Gambar 3) maja digambarkan tersebar merata di seluruh wilayah Mojokerto dengan intensitas sedang hingga paling tinggi. Sedangkan dalam MDA maja digambarkan hanya tersebar di beberapa area dengan intensitas tinggi.

Besar potensi ditemukannya populasi maja di area lain berdasarkan prediksi distribusi Maxent dan daya adaptasi pohon maja. Kenaikan nilai indeks keanekaragaman juga memungkinkan apabila ditemukan lebih banyak sampel ditemukan di dataran tinggi. Ketinggian dan intensitas radiasi berperan besar pada perubahan morfologi tanaman (Radice \& Arena, 2015).

Berdasarkan perbandingan MDA dan PDM, dapat disimpulkan ada penurunan massif populasi maja di sebagian besar wilayah Mojokerto. Keadaan tersebut berkaitan erat dengan alih fungsi lahan yang semakin marak terjadi di Mojokerto (Walhi Jatim, 2018). Warga lokal menuturkan jika pembangunan kawasan industri merupakan salah satu konversi lahan yang paling berdampak pada turunnya populasi maja di kaki Gunung Penanggungan.

\section{Keanekaragaman Morfologi}

Keanekaragaman morfologi maja di Mojokerto diukur dengan parameter kualitatif dan kuantitatif. Pencatatan parameter kualitatif meliputi pola tumbuh pohon, warna batang, bentuk ujung dan pangkal daun, permukaan dan warna daun, bentuk dan warna kulit buah, ujung dan dasar buah. Pencatatan parameter kuantitatif meliputi tinggi tanaman, diameter batang, panjang daun, lebar daun, panjang buah, dan lebar buah. Identifikasi menunjukkan morfologi $C$. cujete dengan $A$. marmelos cenderung sama. Perbedaan keduanya terdapat pada pola tumbuh batang dan bentuk buah. Disimpulkan jika 
lingkungan homogen menyebabkan sedikitnya variasi morfologi karena faktor lingkungan berpengaruh besar pada variasi morfologi (Sari, 2012).

Berdasarkan hasil identifikasi didapatkan 3 bentuk buah maja yaitu globose, ovate, dan round (Gambar 4). Ada 4 karakter warna kulit buah yang berhasil diidentifikasi yaitu hijau pucat, hijau, hijau tua, dan hijau kekuningan. Tiga karakter bentuk atas dan dasar buah yaitu shallow, depressed, dan flattened karakter bentuk atas dan dasar buah yaitu shallow, depressed, dan flattened.

Berdasarkan hasil identifikasi morfologi daun maja didapatkan 3 bentuk ujung daun, 4 bentuk dasar daun, 2 karakter permukaan daun, dan 3 variasi warna daun. Tiga karakter ujung daun maja yang diamati yaitu acute, aristate, dan acuminate (Gambar 4).

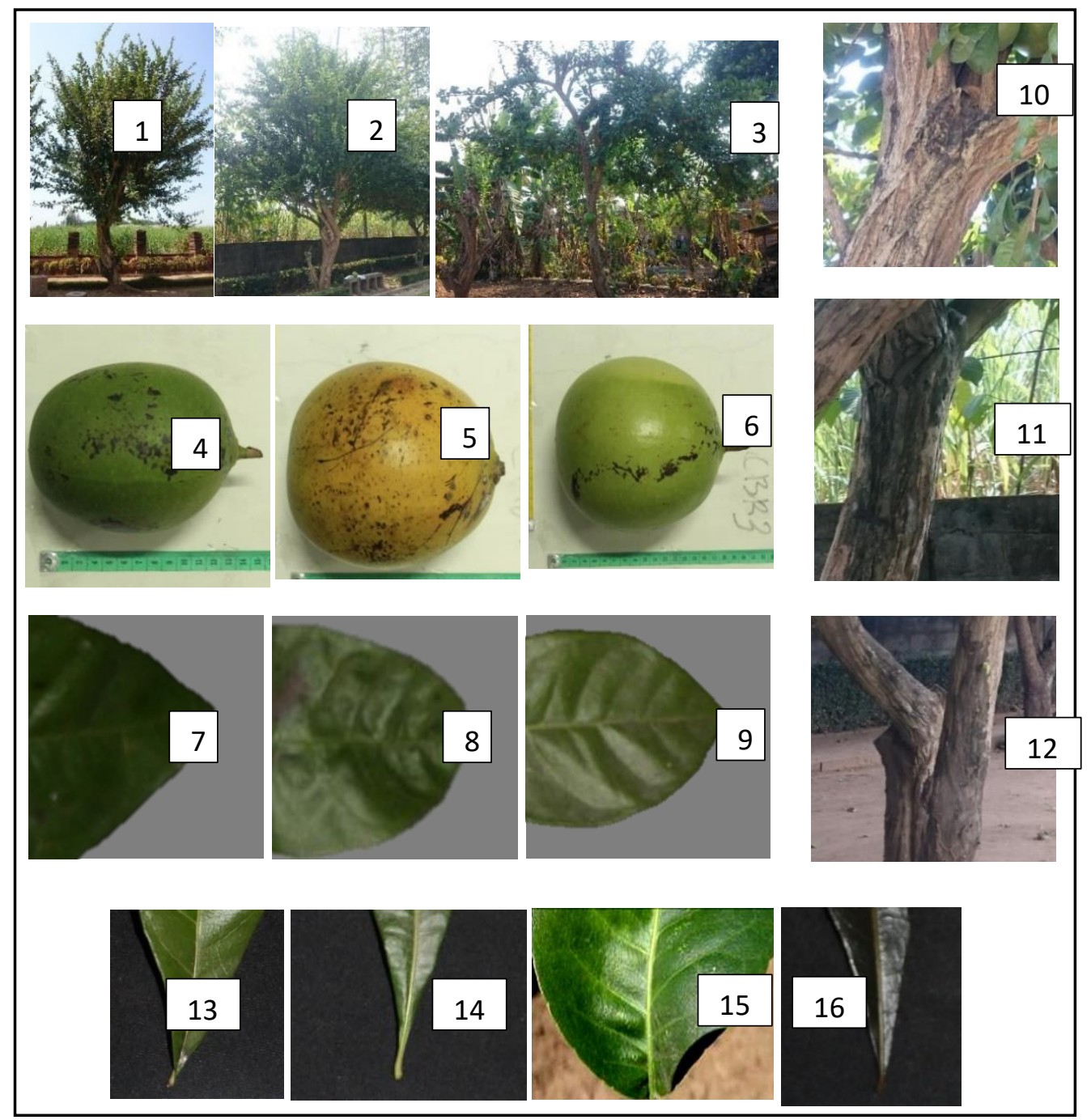

Gambar 4. Karakteristik Morfologi. Pola tumbuh pohon 1) Upright, 2) Spreading, 3) Dropping; Bentuk buah 4) Ovate, 5) Round, 6) Globose; Ujung daun 7) Acuminate, 8) Acute , 9) Aristate; Warna batang 10) Kuning pucat 11) Hijau gelap 12) Hijau kekuningan; Dasar daun 13) Cuneate 14) Attenuate 15) Round 16) Tapering 
Permukaan daun yang berhasil diamati yaitu halus dan kasar. Karakter terakhir yang diamati setelah morfologi buah dan daun yaitu pola tumbuh batang dan warna batang. Ada 3 variasi warna batang yaitu hijau gelap, hijau kekuningan, dan kuning pucat (Gambar 4) serta 3 karakter pola tumbuh batang yaitu dropping, spreading, dan upright.

\section{Analisis Diversitas Karakter}

Analisis keanekaragaman morfologi maja yang telah didata dilakukan dengan perhitungan indeks Shannon. Indeks Shannon memberikan informasi nilai keanekaragaman terbagi mulai dari rendah sedang, hingga tinggi (Indriyani et al., 2017).

Karakter kualitatif memiliki nilai rata rata indeks keanekaragaman sebesar 0,15. Hal ini menjadikan keanekaragaman karakter kualitatif maja tergolong rendah $(\mathrm{H}<1)$ sesuai dengan tingkat keanekaragaman menurut Indriyani et al. (2017). Nilai indeks keanekaragaman terendah pada parameter kualitatif sebesar 0,06 yang terdapat pada karakter dasar daun (Tabel 2). Pola tumbuh batang merupakan karakter dengan nilai indeks tertinggi $(0,25)$ pada karakter kualitatif (Tabel 2). Rendahnya nilai indeks kualitatif menunjukkan sempitnya sebaran maja di Mojokerto.

Tabel 2. Analisis keanekaragaman berdasarkan indeks Shannon.

\begin{tabular}{lclc}
\hline Karakter Kualitatif & Indeks Shannon & Karakter Kuantitatif & Indeks Shannon \\
\hline Pola tumbuh batang & 0,25 & Tinggi tanaman & 4,46 \\
Ujung daun & 0,14 & Diameter batang & 9,49 \\
Dasar daun & 0,06 & Panjang daun & 4,07 \\
Permukaan daun & 0,10 & Lebar daun & 3,16 \\
Warna daun & 0,18 & Panjang buah & 4,46 \\
Bentuk buah & 0,16 & Lebar buah & 4,07 \\
Warna kulit buah & 0,24 & & \\
Styler end cavity & 0,08 & & \\
Stem end cavity & 0,17 & & \\
Warna batang & 0,16 & & \\
\hline
\end{tabular}

Karakter kualitatif memiliki rerata sebesar 0.15 sedangkan karakter kuantitatif menunjukkan nilai indeks yang jauh lebih tinggi (Tabel 2). Ini menunjukkan jika nilai karakter kuantitatif memiliki tingkat keanekaragaman yang tinggi $(\mathrm{H}>3)$. Tingginya nilai keanekaragaman menunjukkan kesesuaian iklim dengan potensi genetik maja (Nurhuda et al., 2017). Pada parameter kuantitatif nilai indeks diameter batang merupakan nilai tertinggi sebesar 9,49. Lebar daun adalah karakter dengan nilai Indeks terendah pada parameter kuantitatif sebesar 3,16.
Secara umum keanekaragaman morfologi maja di Mojokerto memiliki nilai indeks 1,95. Ini menunjukkan tingkat keanekaragaman morfologinya tergolong sedang $(1<\mathrm{H}<3)$ menurut (Indriyani et al., 2017). Ini diduga karena sebagian besar maja berada dalam lingkungan yang hampir seragam. Sampel maja hanya ditemukan di dataran rendah.

\section{Kekerabatan Maja di Mojokerto}

Berdasarkan analisis neighbor-Joining didapatkan ada 4 kelompok dari 35 sampel. Walaupun memiliki spesies yang sama, sampel $A$. marmelos CB1 dan CB2 berbeda 
kelompok dengan HYW 1. Sample CB1 dan CB2 lebih dekat kekerabatannya dengan sample C. cujete seperti Jetis 2 dan CJ3. Perubahan karakter morfologis maupun genetis bisa terjadi setelah melalui banyak faktor selektif (temperatur, intensitas matahari, kelembaban) yang memicu terjadinya evolusi konvergen (Cacho, 2019).

Kelompok pertama terdiri dari 16 sampel (Gambar 5). Karakter kelompok ini memiliki batang berwarna hijau-kekuningan dengan pola tumbuh spreading, ujung daunnya acute, dasar daunnya cuneate, permukaan daunnya halus, warna daunnya hijau gelap, buah berbentuk round, kulit buahnya berwarna hijau kekuningan, buah bagian atas dan bagian bawah buahnya bertipe shallow.

Kelompok kedua terdiri dari 3 sampel (Gambar 5). Kelompok ini memiliki karakter batang berwarna kuning pucat, pola tumbuhnya spreading, ujung daunnya acute, dasar daunnya tapering, permukaan daunnya halus, warna daunnya hijau, buahnya bulat dengan kulitnya berwarna hijau kekuningan, buah bagian atas dan bagian bawahnya bertipe depressed.

Terdapat 3 sampel pada kelompok ketiga (Gambar 5). Karakter kelompok ketiga yaitu batang Hijau gelap dengan karakter tumbuhnya dropping. Ujung daunnya bertipe acuminate dan dasar daunnya bertipe tapering. Kelompok ini memiliki warna daun hijau tua dengan permukaan daun yang halus. Kelompok ini juga memiliki karakter buah yang berbentuk ovate dengan kulit buah berwarna hijau yang bagian atas dan bagian bawah buahnya bertipe shallow.

Kelompok keempat memiliki 13 sampel (Gambar 5). Kelompok ini memiliki ciri batang berwarna hijau kekuningan dengan pola pertumbuhannya spreading. Daun pada kelompok ini memiliki karakter berwarna hijau, permukaan halus, ujungnya acute, dan dasarnya tapering. Kelompok ini juga memiliki karakter buah berwarna hijau dengan buah berbentuk bulat. Bagian atas buahnya bertipe shallow dan bagian dasar buahnya bertipe shallow.

Berdasarkan analisa hierarchical clustering didapatkan 3 kelompok dari 35
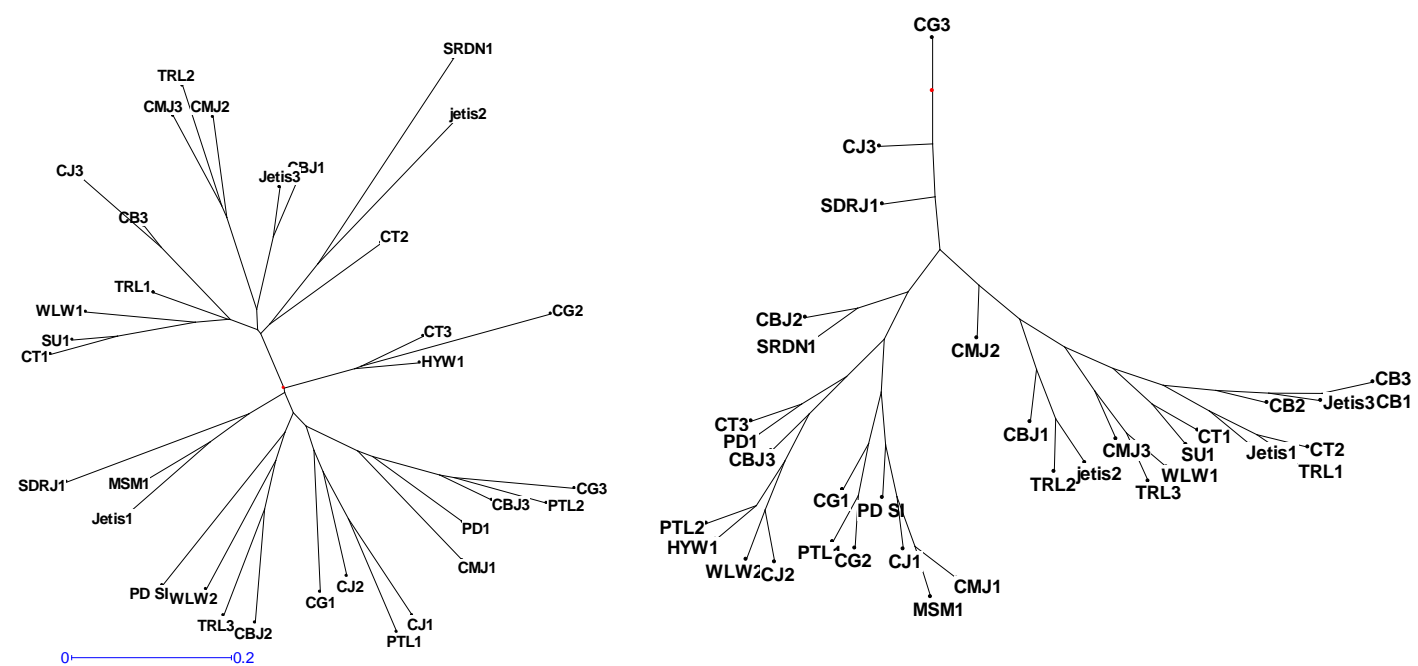

Gambar 5. Grafik kekerabatan hasil analisis neighbor-joining (kiri) dan hierarchical clustering (kanan). 
sampel. Kelompok pertama merupakan kelompok dengan jumlah sampel paling sedikit. Kelompok ini terdiri dari 3 sampel (Gambar 5). Karakter dari kelompok pertama yaitu memiliki tinggi pohon ratarata sebesar 1,8 meter dengan keliling batang rata-rata sebesar $31 \mathrm{~cm}$. Daun pada kelompok pertama memiliki panjang ratarata $9 \mathrm{~cm}$ dengan lebar daun rata-rata $4 \mathrm{~cm}$. Karakter buah pada kelompok pertama memiliki rata-rata panjang sebesar $11.2 \mathrm{~cm}$ dan lebar 9,5 cm

Kelompok kedua terdiri dari 16 sampel (Gambar 5). Kelompok kedua memiliki tinggi pohon rata-rata sebesar 6,5 meter dengan keliling batang sebesar $58 \mathrm{~cm}$. Karakter daun pada kelompok ini memiliki rata-rata panjang sebesar 10,2 cm dengan lebar daunnya sebesar $4,5 \mathrm{~cm}$. Kelompok ini juga memiliki rata-rata panjang buah sebesar $14,2 \mathrm{~cm}$ dan lebar buahnya sebesar $13,1 \mathrm{~cm}$.

Kelompok ketiga merupakan kelompok yang tidak memiliki karakter buah. Kelompok ini terdiri dari 16 sampel (Gambar 5). Kelompok ini memiliki pohon dengan ciri-ciri tinggi rata-rata sebesar 5,2 $\mathrm{m}$ dan diameter batang sebesar 42,6 cm. Kelompok ini juga memiliki karakter panjang daun rata-rata sebesar $8,6 \mathrm{~cm}$ dengan rata-rata lebarnya sebesar $4,2 \mathrm{~cm}$.

\section{SIMPULAN}

1. Keanekaragaman hayati maja di Mojokerto tergolong sedang dengan nilai indeks 1,95. Kekerabatan maja terbagi atas 4 kelompok berdasarkan sifat kualitatif dan 3 kelompok berdasarkan kuantitatif.

2. Maja menyebar di Mojokerto dan terkonsentrasi di 4 kecamatan yaitu Trowulan, Jetis, Kota Mojokerto, dan
Ngoro. Berdasarkan perbandingan dengan prediksi Maxent, terjadi penurunan populasi maja secara masif di Mojokerto.

\section{DAFTAR PUSTAKA}

Álvarez, N. P. C., Vincent, H., Kell, S., Eastwood, R., \& Maxted, N. (2011). Chapter 14: Ecogeographic surveys. Collecting Plant Genetic Diversity: Technical Guidelines-2011 Update, 1-23.

Atul, N. P., Nilesh, V. D., Akkatai, A. R., Kamlakar, S. K., \& Shahu, S. R. (2012). A review on Aegle marmelos: a potential medicinal tree. International Research Journal of Pharmacy, 3(8), 86-91.

https://doi.org/10.5281/zenodo.8532 97

Bartelme, N. (2012). Geographic Information Systems. In W. Kresse \& D. . Danko (Eds.), Springer Handbook of Geographic Information (pp. 145174). https://doi.org/10.1007/978-3540-72680-7

Cacho, N. I., Monteverde-Suárez, M. J., \& Mclntyre, P. J. (2019). Convergent evolution in floral morphology in a plant ring species, the Caribbean Euphorbia tithymaloides. American Journal of Botany, 106(7), 1032-1045. https://doi.org/10.1002/ajb2.1318

Herbei, M. V., Ciolac, V., Smuleac, A., Nistor, E., \& Ciolac, L. (2010). Georeferencing of topographical maps using the software Arcgis. Research Journal of Agricultural Science, 42(3), 595-606.

Indriyani, L., Flamin, A., \& Erna. (2017). Analisis keanekaragaman jenis tumbuhan bawah di Hutan Lindung Jompi. Ecogreen, 3(1), 49-58. 
Karnau, H. N. (1992). Germplasm exploration and collection. Dinteria, $23,50-54$.

Khandare, M. S. (2016). Bael (Aegle marmelos) a Kalpavraksha. Journal of Medicinal Plant Studies, 4(2), 13-14.

Lambole, V. B., Murti, K., Kumar, U., Bhatt Sandipkumar, P., \& Gajera, V. (2010). Phytopharmacological properties of Aegle marmelos as a potential medicinal tree: an overview. International Journal of Pharmaceutical Sciences Review and Research, 5(2), 67-72.

Lesly, W. D., Gunarathne, D. D., \& Jayasinghe, D. J. A. C. D. (2017). Floral biology, pollination behavior and reproduction biology of bael fruit (Aegle marmelos L.) cultivars grown in low country wet zone in Sri Lanka. Annals of Sri Lanka Department of Agriculture, 19, 209-221.

Marshall, D. R., \& Brown, A. H. D. (1975). Optimum sampling strategies in genetic conservation. In O. H. Frankel \& J. G. Hawkes (Eds.), Crop Genetic Resources for Today and Tomorrow (pp. 53-80). Cambridge University Press.

Miller, J. (2010). Species distribution modeling. Geography Compass, 4(6), 490-509.

https://doi.org/10.1111/j.1749-

8198.2010.00351.x

Nurhuda, A., Yusnita, \& Hapsoro, D. (2017). Identifikasi karakter kuantitatif dan kualitatif beberapa varietas tomat (Lycopersicon esculentum Mill.). Agrotek Tropika, 5(2), 68-74. https://doi.org/http://dx.doi.org/10.2 3960/jat.v5i2.1829

Orwa, C., Mutua, A., Kindt, R., Jamnadass, R., \& Anthony, S. (2009). Agroforestree
Database:a tree reference and selection guide version 4.0 (Vol. 0). World Agroforestry Centre.

Palaghianu, C. (2014). A tool for computing diversity and consideration on differences between diversity indices. Journal of Landscape Management, 5(2), 78-82.

PPV \& FRA. (2011). Guidelines for the Conduct of Test for Distinctiveness, Uniformity and Stability of Bael (Aegle marmelos Correa ). Protection of Plant Varieties and Farmer's Right Authority, Government of India.

Radice, S., \& Arena, M. E. (2015). Environmental effect on the leaf morphology and anatomy of Berberis microphylla G. Forst. International Journal of Plant Biology, 6(1), 1-7. https://doi.org/10.4081/pb.2015.567 7

Sari, V. R. (2012). Variasi Morfologi Tanaman Kepel (Stelechocarpus burahol Hook. F \& Thomson) yang Tumbuh pada Ketinggian Berbeda. Universitas Airlangga.

Vinolia, I. (2014). Persebaran dan Karakter Populasi Maja (Aegle marmelos L. Correa) di Situs Candi Trowulan Kecamatan Trowulan Kabupaten Mojokerto. Universitas Islam Negeri Maulana Malik Ibrahim.

Walhi Jatim. (2018). Alih Fungsi Lahan Produktif Mengancam Keberlangsungan Lingkungan Hidup. Media Walhi.

Zonneveld, M. V., Thomas, E., Galluzzi, G., \& Scheldeman, X. (2011). Chapter 15 / 16: Mapping the ecogeographic distribution of biodiversity and GIS tools for plant germplasm collectors. Collecting Plant Genetic Diversity: Technical Guidelines-2011 Update, 1-26. 